8. Muschter D. Sympathetic neurotransmitters modulate osteoclastogenesis and osteoclast activity in the context of collageninduced arthritis. PLoS One. 2015. Vol. 10. No 10. e.0139726. https://doi.org/10.

9. Jänig W., Green P.G. Acute inflammation in the joint: its control by the sympathetic nervous system and by neuroendocrine systems. Auton. Neurosci. 2014. Vol. 182. No 5. P. 42-54.

10. Фізична, реабілітаційна та спортивна медицина: підручник / В. М. Сокрут та ін; за заг. ред. В. М. Сокрута. Краматорськ: Каштан. 2019. $480 \mathrm{c}$.

11. Levine Y.A., Koopman F.A., Faltys M. Neurostimulation of the cholinergic anti-inflammatory pathway ameliorates disease in rat collageninduced arthritis. PLoS One. 2014. Vol. 9, No 8. E. 104530.

DOI https://doi.org/10.30525/978-9934-588-81-5-1.49

\title{
ВИПАДОК ДІАГНОСТИКИ ТА ЕНДОСКОПІЧНОГО ВИДАЛЕННЯ ПІСЛЯОПЕРАЦИЙНОГО СТОРОННЬОГО ТІЛА НАДПЕЧІНКОВОГО ПРОСТОРУ
}

\author{
Ступницький А. І. \\ лікар-ендоскопіст, хірург \\ Медичний иентр Святої Параскеви \\ Гула Г. В. \\ кандидат медичних наук, \\ лікар-ендоскопіст \\ Медичний ичентр Святої Параскеви \\ Ступницька Н. Д. \\ лікар-радіолог \\ Медичний иентр Святої Параскеви \\ Шев'як П. І. \\ лікар-хірург \\ Медичний центр Святої Параскеви \\ м. Львів, Украӥна
}

Вступ. Проблема післяопераційних сторонніх тіл (ПСТ) була й залишається актуальною упродовж усієї історії хірургії $[2,6,10,11]$. ПСТ є ятрогенним хірургічним післяопераційним ускладненням, частота якого - від 0,3 до 1 на 1000 черевних операцій $[2,7,11]$. Смерт- 
ність, пов'язана із ПСТ, сягає $11 \%-35 \%[4,6,9]$. Найчастіше ПСТ - це залишені хірургічні губки (марлеві серветки), які отримали назву «госпіпібома» або «текстилома» $[4,5,8]$.

Підрахунок хірургічних матеріалів, що використовуються під час операцій, є обов'язком медичних сестер під керівництвом лікарів, однак його чутливість - лише $77 \%[3,8]$. Майже $90 \%$ випадків діагностовано ПСТ - це випадки, коли кількість заявлених на кінець операції матеріалів була правильною [1,3]. Ризик ПСТ при тривалих ургентних втручаннях суттєво зростає. 3 метою своєчасного виявлення ПСТ необхідною $є$ його рентгеноконтрастність, яка у марлевих серветок, як правило, відсутня [6,9].

Симптоматика ПСТ $є$ неспецифічною, найчастіше виникає місцева та загальна запальна реакція, водночас пацієнти із асептичною фіброзною реакцією залишаються безсимптомними $[4,5,7,11]$. У разі хронічного перебігу відбувається абсцедування, у близько $20 \%$ випадків перфорація внутрішніх органів чи непрохідність кишечника, формуються різні види нориць $[5,10]$. При підозрі на ПСТ діагноз повинен бути підтверджений комп'ютерною томографією (КТ) $[9,11]$. Як правило, видалення стороннього тіла з черевної порожнини потребує лапароскопічного втручання або лапаротомного розрізу $[6,7]$. У близько 80\% випадків після видалення ПСТ пацієнти потребують повторного втручання $[4,11]$.

При аналізі медичної літератури ми не виявили повідомлень про ендоскопічне лікування ПСТ черевної порожнини.

Мета роботи. Представити випадок ПСТ надпечінкового простору та власний досвід його ендоскопічного видалення.

Матеріали та методи. Чоловік, 52 р., скерований після ультразвукової діагностики (УЗД) черевної порожнини на комп’ютерну томографію (КТ) черевної порожнини з метою уточнення виявлених змін. Скарги при цьому неспецифічні - упродовж останніх 8 місяців турбують геморагічні висипання на гомілках, загальна слабість. Консультований ревматологом, діагноз: «Вторинний геморагічний васкуліт. Ожиріння 2 ступеня». Лабораторно: ШОЕ 13 мм/год; із біохімічних показників підвищена АЛТ 80 Од/л, сечова кислота 532 мкмоль/л; також - AntiТРО. У анамнезі - холецистектомія (2014p.), після чого щорічно - УЗДконтроль. Лише через 4 роки після операції у нашій клініці при УЗД виявлено гіперехогенний утвір до 4 см. За результатами КТ на рівні $\mathrm{S} 4$ - супракапсулярне утворення 50х25мм. Припущено паразитарне походження, малоймовірно - неопластичний процес.

Упродовж наступних 1,5 року наростав біль у правому підребер'ї, періодично - субфебрильна температура тіла. Проведено повторне КТ: у правому піддіафрагмальному просторі інкапсульований утвір 
50x27x80мм, з незначним контрастним підсиленням стінок, негомогенної структури; на рівні S4 печінка 3 деформованим контуром за рахунок зовнішньої компресії паренхіми вищевказаним утвором. Висновок: Утвір піддіафрагмального простору справа (corp. alienum, організована гематома?), з реактивними запальними змінами прилеглих тканин (піддіафрагмального простору, правої підреберної ділянки). Призначено Антитіла IgG до ехінококів, консультацію інфекціоніста, планову діагностичну лапароскопію.

Через 2 місяці у клініці, в якій виконували холецистектомію, проведено дренування гематоми передньої черевної стінки (ПЧС). Після даного втручання упродовж 3 тижнів поступово виникли гнійні виділення із ділянки п/о рубця правого підребер'я. При УЗД піддіафрагмально вкотре виявлено неоднорідний гіпоегогенний утвір, який розцінено як абсцес печінки. У районній лікарні за місцем проживання встановлено діагноз флегмони ПЧС, іiі розкрито та дреновано. Виписаний через 2 тижні із гранулюючою п/о раною. Через 3 тижні планова КТ: у піддіафрагмальному просторі справа неоднорідний утвір $21 \times 47 \times 50$ мм, негомогенної структури, 3 формуванням норицевого ходу діаметром до 8мм від описаного утвору до зони п/о рубця правої ПЧС. Висновок: стан після розкриття та дренування флегмони ПЧС; ознаки абсцесу в піддіафрагмальному просторі справа, з компресією печінки та формуванням норицевого ходу, з реактивними запальними змінами прилеглих м'яких тканин (піддіафрагмального простору, правої підреберної ділянки). Того ж дня виконано ревізію п/о рани: введено дренажну трубку до 12 см, густий гній аспіровано, порожнину промито, виконано фістулографію. Враховуючи дані КТ, рекомендовано лапароскопічне видалення вогнища 3 надпечінкового простору та санацію норицевого ходу.

Пацієнт через 2 тижні із скаргами на ниючий біль в животі, гнійні виділення $з$ рани та попереднім діагнозом «Хронічний абсцес надпечінкового (піддіафрагмального) простору з формуванням фістули та підшкірного абсцесу передньої черевної стінки» звернувся до нашої клініки 3 метою хірургічного втручання. За даними КТ, ймовірно сторонне тіло в порожнині абсцесу між печінкою та діафрагмою 3 норицевим ходом до правої бокової ділянки живота та розкриттям на поверхню шкіри.

Результати. Вирішено провести ендоскопічну ревізію норицевого ходу і порожнини абсцесу. Status localis: на шкірі правої підреберної ділянки наявний округлий дефект діаметром близько 5мм 3 помірним перифокальним запаленням і серозно-гнійними виділеннями. Краї його оброблено спиртовим розчином та знечулено гелем з лідокаїном. Ендоскоп Fujifilm EG-740N без труднощів проведено сформованим 
норицевим ходом діаметром близько 5мм на глибину 9см у напрямку простору між печінкою, правою реберною дугою і куполом діафрагми. На відстані 9 см від поверхні шкіри норицевий хід переходить у неправильної овальної форми порожнину, протяжністю бсм по довшій осі, з множинними фібриновими й фіброзними переділками та кишенями по типу дивертикулів. У порожнині розташоване ПСТ (марлева тканина). Порожнину абсцесу промито розчином Декасану. Інструментом для видалення сторонніх тіл типу «алігатор» виконано часткове поетапне видалення фрагментів марлевої тканини, захоплено і підтягнуто до поверхні шкіри один кінець ПСТ й хірургічним затискачем видалено повністю. Виконано ревізію норицевого ходу і порожнини абсцесу, видалено поодинокі нитки, фібрин та гнійні нашарування, промито розчином Декасану, дреновано. Видалене ПСТ є марлевою турундою довжиною $24 \mathrm{~cm}$, діаметром до $1 \mathrm{~cm}$. Висновок: сформований абсцес правого піддіафрагмального простору із стороннім тілом (марлева турунда); стан після ендоскопічного видалення стороннього тіла і санації порожнини абсцесу. Status localis через 2 тижні: видалено дренаж 3 норицевого ходу; виділень нема, рана очистилася й гоїться вторинним натягом.

Висновки. Мультидисциплінарний командний підхід дозволив встановити точний діагноз у непростому клінічному випадку залишеного після лапароскопічної операції стороннього тіла. Успішно застосоване ендоскопічне видалення післяопераційного стороннього тіла черевної порожнини у пацієнта після лапароскопічної холецистектомії через сформовану зовнішню норицю дало змогу уникнути оперативного втручання й стало радикальним способом лікування.

\section{Література:}

1. Brisson P. Prevention of retained foreign objects. Bull Am Coll Surg. 2009. Vol. 94. N. 11. P. 28-31.

2. Gawande A.A., Studdert D.M., Orav E.J., Brennan T.A., Zinner M.J. Risk factors for retained instruments and sponges after surgery. N Engl J Med. 2003. Vol. 348. N. 3. P. 229-35.

3. Gibbs V.C., Coakley F.D., Reines H.D. Preventable errors in the operating room: retained foreign bodies after surgery, Part I. Curr Probl Surg. 2007. Vol. 44. N. 5. P. 281-337.

4. Kaiser C.W., Friedman S., Spurling K.P., Slowick T., Kaiser H.A. The retained surgical sponge. Ann Surg. 1996. Vol. 224. N. 1. P. 79-84.

5. Mouhsine E, Halkic N, Garofalo R, Taylor S, Theumann N, Guillou L, et al. Soft-tissue textiloma: a potential diagnostic pitfall. Can J Surg. 2005. Vol. 48. N. 6. P. 495-6. 
6. Stawicki SP, Evans DC, Cipolla J, Seamon MJ, Lukaszczyk JJ, Prosciak MP, et al. Retained surgical foreign bodies: a comprehensive review of risks and preventive strategies. Scand J Surg. 2009. Vol. 98. N. 1. P. 817.

7. Stawicki SP, Moffatt-Bruce SD, Ahmed HM, Anderson HL, 3rd, Balija TM, Bernescu I, et al. Retained surgical items: a problem yet to be solved. J Am Coll Surg. 2013. Vol. 216. N. 1. P. 15-22.

8. Wan W, Le T, Riskin L, Macario A. Improving safety in the operating room: a systematic literature review of retained surgical sponges. Curr Opin Anaesthesiol. 2009. Vol. 22. N. 2. P. 207-14.

9. Wieder HA FH, Rummeny EJ, Gaa J. Radiological diagnosticsfor iatrogenic retained foreign bodies after surgery. Chirurg. 2007. Vol. 78. P. 22-27.

10. Zbar A.P., Saeed I.T., Utidjian M.R. Gossypiboma revisited: a case report and review of the literature. J R Coll Surg Edinb. 1998. Vol. 43. P. 417-418.

11. Zejnullahu V.A., Bicaj B.X., Zejnullahu V.A., Hamza A.R. Retained Surgical Foreign Bodies after Surgery. Open Access Maced J Med Sci. 2017. Vol. 5, N. 1. P. 97-100.

DOI https://doi.org/10.30525/978-9934-588-81-5-1.50

\title{
ПСИХОЛОГІЧНА ДІАГНОСТИКА БОЛЬОВОГО СИНДРОМУ
}

\author{
Фітькало О. С. \\ кандидат медичних наук, \\ доиент кафедри психіатрії та психотерапії \\ факультету післядипломної освіти \\ Львівського національного університету імені Данила Галицького \\ м. Львів, Украӥна
}

Швидкий розвиток сучасного урбанізованого суспільства призводить до збільшення його впливу на особистість, що характеризується як «тиск» на психіку, яка шляхом усунення надмірного емоційного напруження запобігає дезорганізації поведінки через прояви болю. Така біль трактується як болісний спосіб примирення індивіда 3 неприйнятною для нього інформацією і являється його психічним захистом. Питання боротьби людини з болем своїми коренями веде в глибину століть. Про це свідчать усні перекази старовини, древні міфи висічені на камені та записані на старовинному пергаменті, художні 